\title{
The effect of slash
}

\section{and burn agriculture on plant nutrients in the Tertiary Region of Central Amazonia

\author{
W. L, F, BRINKMANN(") \\ J. C. DO NASCIMENTo(**)
}

\begin{abstract}
The slash and burn method was studied with respect to changes on the chemical composition in the top-soil layer (upper $20 \mathrm{~cm}$ ) of yellow latosols (about $85 \%$ of the total area) and hydromorphic soils (about $1 \%$ of the total area) before and after fire was set on the cleared forest. The obtained. analytical data prove the following results: 1) the soil fertility of latosols and hydromorphic soils is considerably low as far as natural conditions are concerned, 2) after burning a considerable amount of plant nutrients normally bound to the standing crop is lost in the form of volatiles and particles during the burning procedures, 3) a great amount of plant nutrients is rapidly released to the soil after burning, 4) great quantities of temporarily available nutrients are lost by leaching as the nutrient uptake capacity of the crops is not able to match the excess of available plant nutrients, 5) strong nutrient fixation will reduce the availability of present plant nutrients remarkably, 6) the nutrient return from standing crop bound nutrients by means of fire is not able to guarentee long-term tropical agriculture, 7) correction of soil $\mathrm{pH}$ by means of heavy liming and the application of fertilizers is a basic need in tropical landuse systems, 8) the treatment with herbicides, insecticides and fungicides is indispensable to reduce root competion and plant deseases and 9) favourable conditions as far as the impact of atmospheric agents on the crops is concerned has to be set up by means of crop specific shelter-wood systems.
\end{abstract}

\section{INTRODUCTION}

Tropical agriculture and recent cattle breeding in Central Amazonia are primarily based on slash and burn. Clearing and burning the climax forest is understood to be a con- venient and economic method to bring a natural forest area of relatively low economic value to a higher state of yield.

Without any doubt, the ecological equilibrium of such areas will be changed, as the impact of atmospheric controls as solar radiation, air temperature, air humidity, wind, etc. come into play with a modified efficiency (Brinkmann and Vieira, 1971, Brinkmann and Góes Ribeiro, 1971) .

Although labor is quite inexpensive, the extremely high costs for NPK-fertilizer in Central Amazônia out the profits down and partially block the development of an intensive land-use. With this in view, the available plant nutrients in the soils after burning are quantitatively and qualitatively of considerable interest in agricultural planning and development.

\section{MLATERIAL AND METHODS}

In 1970, a tropical rain forest site was selected for the establishment of a cacao experimental scheme near $\mathrm{Km} 30$ of the Manaus-Itacoatiara Road (fig. 1). The SEMA (Serviço Experimental em Manaus) manages an area of about $30 \mathrm{ha}$, a donation of the state government.

Actually, the site was covered by a terra firme rain forest typical for the "chapadas" of the Tertiary formations along the Road AM-10. The area was floristically inventorized in 1965 (Rodrigues, 1967). The dominant tree species of the 137000 ha forest inventory, counting only trees with a stem-diameter above $25 \mathrm{~cm}$

(*) - Instituto Nacional de Pesquisas da Amazônia.

(**) - CEPEC, Itabuna, Bahia.

(1) - Granted by Banco Nacional de Desenvolvimento Econômico under contract INPA/FUNTEC 89/70. 


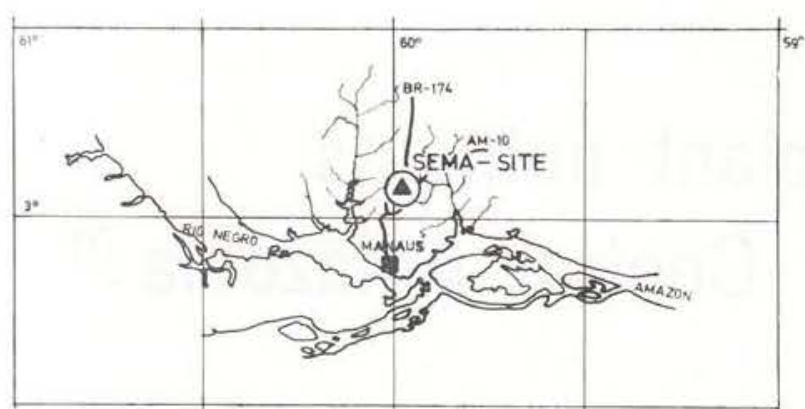

Figura 1 - SEMA-site - a cacao pilot scheme in Central Amazonia

(DBH) were: Eschweilera spp (6.5 trees/ha), Scleronema micranthum Ducke (3.4 trees/ha), Corythopora alta Knuth (2.9 trees/ha) and Ragala spuvia (Ducke) Aubr. (2.2 trees/ha) . According to Takeuchi (1961) more than $40 \%$ of all trees above $10 \mathrm{~cm}$ in diameter (DBH) belonged to the families Leguminosae Letythidaceae and Sapotaceae.

The canopy height of the "chapada" forest ranged from $25 \mathrm{~m}$ to $35 \mathrm{~m}$ and different canopy strata were partially well developed. Epiphytes, Bromeliaceae and Orchidaceae were abundant, trailing lianas quite common. Various palms like Astrocaryum munbaca, Syagrus inajai, Bactris $s p$ et. al. and saplings formed the substratum. A dense community of countless seedlings, stemless palms and herbs covered the ground. Normally the litter layer was well developed, but in some places hardly a litter layer occured.

The soils along the Manaus-Itacoatiara Road (fig. 1) were inventorized by a research group of the Instituto de Pesquisas e Experimentação Agropecuária do Norte in Belém, state of Pará (IPEAN, 1969). Nearly $85 \%$ of the soils mapped were yellow were latosols ranging over a textural spectrum from very heavy to light. The physical properties of these soils were good, while the chemical properties were quite unfavourable as far as the agricultural potentials of these soils were concerned.

This in mind, the slash and burn system was tested whether the release of plant nutrients bound to the standing crop is able to provide a saficiently high and permanent nutrient supply for the growth of various tropical crops, such as maniok, bananas, beans, black pepper, cacao, et. al.
In late May 1970, an area of 26 ha at the experimental site (fig. 1) was subdivided into 7 equal-sized plots of approximately 4 ha each. The terra firme rain forest was cut down and soil samples were collected in $20 \mathrm{~cm}$ depth of the soil profiles (fig. 2). Ten subsamples at a time were thoroughly mixed to one prime soil sample, which was taken to the laboratory to be analyzed. While the soil samples No. 1 to No. 6 were collected from heavy to very heavy latosols, soil sample No. 7 was taken from a hydromorphic soil near a small rain forest stream (tab. 1).

In late August 1970 the chaotic mass of out down forest had dried up sufficiently and was set on fire. The soil samples were collected on the 13th, the 148th and the 290th day after burning (fig. 2). The sampling procedures were the same as those mentioned above.

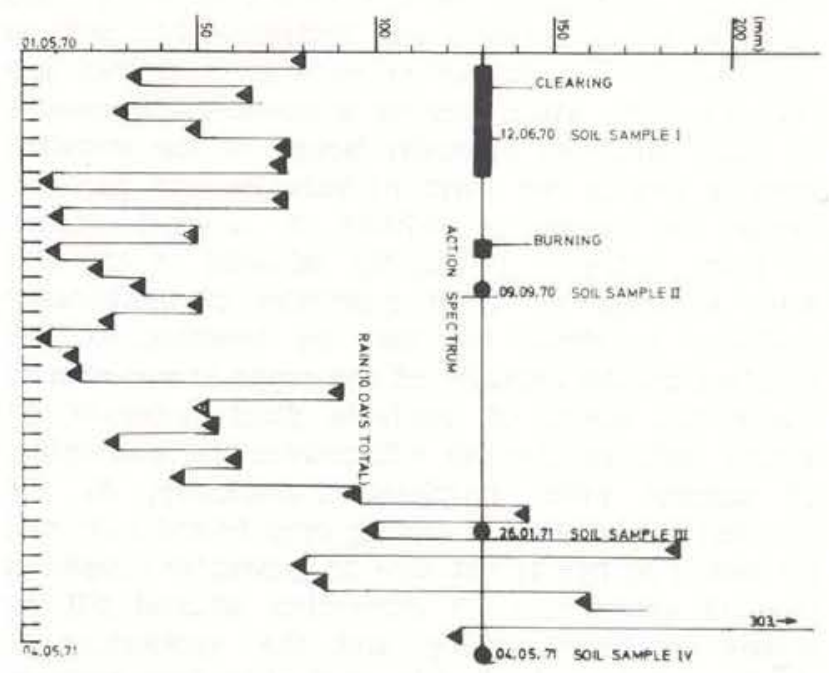

Figura 2 - Action spectrum (clearing, burning, soil sampling) and 10 days total of rainfall from May lst, 1970 to May 4th, 1971, at SEMA-site.

\section{RESULTS AND DISCUSSION}

The hydrogen-ion concentration $(\mathrm{pH})$, calcium and magnesium, potassium, phosphorus and aluminum were determined in yellow latosols and hydromorphic soils at the experimental site (fig. 1) near $\mathrm{Km} 30$ of the Manaus-Itacoatiara Road (AM-10) before and after burning was applied

The soil analyses carried out before burning showed the following natural soil conditions:

The soil $\mathrm{pH}\left(\mathrm{pH} / \mathrm{H}_{2} \mathrm{O}\right)$ of both soil groups was very low (range: $\mathrm{pH} 3.6$ to $\mathrm{pH} 4.1$ ). When 
crops as cacao. black pepper, et. al. are introduced to such soils the soil $\mathrm{pH}$ has to be corrected by means of liming. Limestone is not available in Central Amazônia, which makes the costs for such treatments excessive.

The calcium and magnesium concentrations in both soil groups are low (range : $0.20 \mathrm{ME} \%$ to $0.50 \mathrm{ME} \%$ ). Both ions, however, are accumulated in the standing crop. Calcium is often immobilized in trees in the form of cristals of calcium oxalate, as calcium phosphate or forms salts with various organic acids. Magnesium is the only mineral constituent in the clorophyll molecule. As large parts of the calcium present in the plant tissue are located in older leaves, a conciderable amount of the ion must be exspected to be accumulated in the litter layer. The yearly calcium and magnesium return to the soil of a terra firme rain forest near $\mathrm{Km} 64$ of the Road AM-10 was calculated with $17 \mathrm{Kg} / \mathrm{ha}$ for calcium and $12 \mathrm{Kg} / \mathrm{ha}$ for magnesium (Klinge and Rodrigues, 1968). Soluble calcium and magnesium also returned to the forest floor in stemflow and throughfall (Brinkmann and Santos, 1971).

Both soil groups, the yellow latosols and the hydromorphic solls are extremely low in potassium (range : $0.04 \mathrm{ME} \%$ to $0.08 \mathrm{ME} \%$ ) . Bound to the standing crop potassium occurs as soluble inorganic salts and is highly mobile. The potassium return to the forest floor of a "chapada" forest near Km 64 of the Manaus- Itacoatiara Road was in the order of $12 \mathrm{Kh}$. ha $^{-1}$. year-1 (Klinge and Rodrigues. 1968) .

Soil anaiyses data point out, that the topsoil layer of the yellow latosols and the hydromorphic soils at the experimental site are low in extractable calcium, magnesium and potassium. Likewise, this holds for the cation exchange capacity (tab. 2).

The amount of total phosphorus (range : $0.49 \mathrm{ME} \%$ to $0.69 \mathrm{ME} \%$ ) was at very low concentration for both soil groups studied (tab. 1). Phosphorus in plants is linked into organic combinations in highly oxidized form. During growth, phosphorus is accumulated in the seeds and fruits and consequently available in the "standing crop. The phosphorus return to the soil observed at a terra firme rain forest near $\mathrm{Km} 64$ of the Road AM-10 was in the order of $2 \mathrm{Kg} \cdot \mathrm{ha}^{-1}$.year-1 (Klinge and Rodrigues,
1968). A conciderable amount of phosphorus was present in stemflow and throughfall of a similar climax forest at Ducke Forest Reserve, $\mathrm{Km} 26$ of the Manaus-Itacoatiara Road (Brinkmann and Santo's, 1972).

Actually a larger portion of soluble aluminum (range : $1.7 \mathrm{ME} \%$ to $2.1 \mathrm{ME} \%$ ) is present in the acid yellow latosols at the experimental site, while the hydromorphic soils are relatively low in aluminum (tab. 1). The yellow latosols are rich in clay content (about $60 \%$ to $95 \%$ of the total granulometric composition). $\mathrm{SiO}_{2}$ and $\mathrm{Al}_{2} \mathrm{O}_{3}$ are reported to be in the order of $29 \mathrm{~g}$ to $37 \mathrm{~g} / 100 \mathrm{~g}$ air-dried soil and $24 \mathrm{~g}$ to $33 \mathrm{~g} / 100 \mathrm{~g}$ air-dried soil, respectively. Aluminum concentrations increased with depth in all soil profiles studied (IPEAN, 1969).

Organic matter and nitrogen compounds concentrate in the top-soil layer.

Carbon and nitrogen content was quite high for the yellow latosols, but low for the hydromorphic soils (tab. 2). While the clay content in both soil groups increased with depth, the organic matter decreased progressively. A very tight nutrient cycle is typical for the terra firme rain forest in Central Amazonia (Brinkmann and Santos, 1971, Santos et al., 1971, Stark, 1971). Temporarily nutrients are stored in the litter layer, but the principle source of nutrients is the stock accumulated in/ on the standing crop. In fact, fire is a means to make these nutrient deposits rapidly available for tropical agriculture.

After fire was applied to the cut down forest, the soil anaiyses (tab. 1) showed the following results :

Calcium and magnesium concentrations (soil sampling II) increased significantly for the yellow latosols $(400 \%)$ and the hydromorphic soils $(900 \%)$, respectively. This holds as well for the soil $\mathrm{pH}$ which increased slightly (about $0.6 \mathrm{pH}$ ) for the yellow latosols and considerably $(2.8 \mathrm{pH}$ !) for the hydromorphic soils. Calcium and magnesium were released from the burnt litter layer and forest leftovers. The great amount of available calcium and mgnesium in the hydromorphic soils were due to a richer litter layer present before burning. The decay rates of the litter layer are much lower for the hydromorphic soils than those observed on the yellow latosols. During the first period 
of measurements (soil sampling I to soil sampling II), rainfall at the experimental site was in the order of $4.21 . \mathrm{m}^{-2} \cdot$ day $^{-1}$, while between burning and soil sampling II rainfali decreased to $2.21 \cdot \mathrm{m}^{-2}$. day ${ }^{-1}$, i.e. the leaching of soluble calcium and magnesium compounds out of the top-soil layer was limited.

In the second period of measurements (soil sampling II to soil samplin III) rainfall was at about $5.11 \cdot \mathrm{m}^{-2} \cdot$ day $^{-1}$. The rapidly available soluble calcium and magnesium compounds especially from the burnt litter were easily washed through the upper $20 \mathrm{~cm}$ of the soil profiles. Calcium and magnesium concentrations decreased to $100 \%$ for the yellow latosols and $100 \%$ for the hydromorphic soils, respectively, as reported by the analytical data of soil sampling III. The steep decline of calcium and magnesium levels in the hidromorphic soils are due to a higher percolation capacity of the top-soil layer of this particular soil group (only $8 \%$ to $10 \%$ clay content in the top-soil) .

In the third period of measurements (soil sampling III to soil sampling IV) rainfall was in the order of $15.01 . \mathrm{m}^{-2}$.day ${ }^{-1}$, i.e. available leaching water surpassed about 7 times the amount of water available at the periodo burning to soil sampling II, and 3 times that of the period soil sampling II to soil sampling III.

While soluble calcium and magnesium compounds of the burnt litter had been washed through the top-soil layer in the second period of measurements (fig. 2), the great amount of water brought about the leaching of solub!e calcium and magnesium constituents from the forest leftovers as partly deteriorated trunks, branches and remainders of burnt fruits and cinders.

During the third period of measurements (fig. 2) soil moisture is at field capacity (rain season), i.e. the percolation rates are considerably reduced. Consequently soluble calcium and magnesium compounds remain longer a time in the top-soil layer. The temporary accumulation of both constituents is recorded by an recurrent increase in calcium and magnesium concentrations to about $300 \%$ for the yellow latosols and $400 \%$ for the hydromorphic soils. Coincidently the soil $\mathrm{pH}$ increased in consequence of higher calcium and magnesium levels. In comparison to the soil $\mathrm{pH}$ under natural forest conditions the $\mathrm{pH}$ values for both soil groups were at about $0.5 \mathrm{pH}$ higher than the initially observed soil $\mathrm{pH}$.

Evidently the burnt forest leftovers as partially destroyed trunks, branches and fruits are permanently leached. In the course of time, weathering and the continuous utilization of such nutrient deposits by photosynthetic and non-photosynthetic organisms will reduce the available stock to a very minimum. On the other hand, a new source of nutrient supply is not available, as the amount of litter produced by tropical crops is unsufficient and the nutrients stored in the fruits are taken away (Brinkmann, 1971).

Potassium in the standing crop occurs in the form of soluble inorganic salts. After burning, the initially measured concentrations of potassium already extremely low in the yellow latosols and the hydromorphic soils under natural forest conditions increased 31 times and 160 times, respectively. As potassium is highly mobile, the high concentrations shortly after burning decreased rapidly and at the end of the second period of measurements (soils sampling III) only a small departure of potassium concentrations from the initially measured values was reported for both soil groups. Actually at the end of the third period of measurements (fig. 2) potassium concentrations present in the yellow latosols and the hydromorphic soils were at the same levels as analized for soil samples taken from a natural rain forest site.

As referred to natural forest conditions total phosphorus was low in both soil groups. After burning an unsignificant increase in phosphorus was observed in the yellow latosols. The availability of phosphorus in the soil is largely determined by soil $\mathrm{pH}$, and the presence of soluble iron, manganese and aluminum. In the presence of these elements the fixation of phosphorus in the soil will rapidly occur and phosphorus is kept unsoluble and not any more available for plant growth. Phosphorus is one of the nutrient controls of the tight nutrient cycle of the tropical rain forest on the terra firme uplands in Central Amazonia (Brinkmann and Santos, 1972). As the natural nutrient cycle at the experimenta! site was destroyed 
( $M E \%$ )

\begin{tabular}{|c|c|c|c|c|c|c|c|c|c|c|c|c|c|c|c|c|c|c|c|c|}
\hline \multirow{2}{*}{$\begin{array}{c}\text { Sample } \\
\text { No } \\
1\end{array}$} & \multicolumn{4}{|c|}{ Soil $\mathrm{pH}$} & \multicolumn{4}{|c|}{ Calcium + magnesium } & \multicolumn{4}{|c|}{ Potassium } & \multicolumn{4}{|c|}{ Phosphorus } & \multicolumn{4}{|c|}{ Aluminum } \\
\hline & 3.8 & 4.8 & 3.6 & 4.4 & .0 .3 & 1.6 & 0.8 & 2.1 & 0.08 & 0.31 & 0.12 & 0.09 & 0.69 & 0.69 & 0.69 & 0.69 & 1.7 & 0.5 & 1.8 & 0.5 \\
\hline 2 & 3.9 & 4.4 & 3.8 & 4.5 & 0.4 & 1.0 & 1.1 & 2.2 & 0.06 & 0.23 & 0.10 & 0.09 & 0.69 & 0.69 & 0.69 & 0.69 & 1.7 & 0.9 & 1.1 & 0.4 \\
\hline 3 & 3.9 & 4.6 & 3.5 & 4.1 & 0.3 & 1.4 & 0.5 & 1.0 & 0.07 & 0.17 & 0.09 & 0.06 & 0.46 & 0.69 & 0.69 & 0.69 & 1.8 & 0.7 & 1.3 & 1.1 \\
\hline 4 & 4.1 & 4.5 & 3.6 & 4.2 & 0.3 & 1.1 & 0.6 & 1.2 & 0.06 & 0.15 & 0.10 & 0.07 & 0.46 & 0.69 & 0.69 & 0.69 & 1.2 & 0.7 & 1.1 & 0.7 \\
\hline 5 & 3.6 & 4.3 & 3.5 & 4.2 & 0.3 & 1.2 & 0.7 & 1.2 & 0.09 & 0.23 & 0.08 & 0.05 & 0.46 & 0.69 & 0.69 & 0.69 & 2.1 & 0.7 & 1.2 & 0.8 \\
\hline 6 & 3,7 & 4.3 & 3.6 & 4.3 & 0.5 & 1.2 & 0.7 & 1.4 & 0.06 & 0.23 & 0.10 & 0.08 & 0.46 & 0.69 & 0.69 & 0.69 & 1.9 & 0.7 & 1.4 & 0.6 \\
\hline 7 & 3.9 & 6.7 & 3.6 & 4.4 & 0.2 & 1.9 & 0.4 & 1.0 & 0.04 & 0.64 & 0.09 & 0.04 & 6.69 & 2.80 & 0.69 & 0.91 & 0.6 & 0.0 & 0.8 & 0.7 \\
\hline $\begin{array}{c}\text { Soil } \\
\text { Sampling }\end{array}$ & 1 & II & III & IV & 1 & 11 & III & IV & I & II & III & IV & 1 & II & III & IV & 1 & II & III & IV \\
\hline
\end{tabular}

TABLE 1 - Some important chemical constituents in the soils under investigation collected before and after the slash and burn method was carried out.

\begin{tabular}{|c|c|c|c|c|}
\hline & Latosols (E.S.) & Latosols (T.R.) & Hydromorphic soils (E.S.) & Hydromorphic soils (T.R.) \\
\hline Soil extractable cations & 0.80 & $0.40-0.90$ & 1.30 & $0.20 \cdot 1.70$ \\
\hline Cation exchange capacity & 16.00 & $5.20 \cdot 18.60$ & 8.60 & $1.10-11.10$ \\
\hline Carbon content & 2.70 & $2.40-4.70$ & 1.68 & $0.05-3.80$ \\
\hline Nitrogen content & 0.23 & $0.06-0.95$ & 0.11 & $0.02-0.18$ \\
\hline $\mathrm{C} / \mathrm{N}$ ratio & 12.00 & $10.00-25.00$ & 14.00 & $8.00-21.00$ \\
\hline
\end{tabular}


phosphorus must be understood as one of the most important limiting factors in slash and burn agriculture. The hydromorphic soils, however, are considerably low in aluminum, iron and manganese in the to-soil layer. After burning (soil sampling II), the phosphorus content surpassed about 4 times the values measured before burning. At the end of the third period of measurements (fig. 2) the phosphorus content of the top-soil layer of the hydromorphic soils was only slightly higher than that of the analyses of the first series of soil samples (tab. 1).

Before fire was set on the cut down forest, the aluminum content in the yellow latosols was quite high, while that of the hydromorphic soil was about 3 times lower (tab. 1). After burning, the aluminum level in the yellow latosols decreased by a factor 2, while the hydromorphic soil was without aluminum after burning (soil samplin II), but after| the third period of measurements (soil sampling IV) the initially observed aluminum level were reached again. The decrease of aluminum concentrations in the top-soil layer, i.e. the primary root-zone of various tropical crops has a positive effect on the availability of phosphorus for plant growth, which is of some importance when fertilizers are applied.

\section{CONCLUSIONS}

After burning the cut down forest, the soil $\mathrm{pH}$, calcium and magnesium content and potassium increased considerably in the top-soil layer of the yeliow latosols, while phosphorus did not depart from the pre-fire level and aluminum decreased. At the end of the third period of measurements (fig. 2), only calcium and magnesium content and the concentration of aluminum were favourable in the top-soil layer of the latosols, while phosphorus showed up with the same concentration level measured before burning and potassium content decreased heavily because its high mobility due to increasing rainfall $\left(15.01 . \mathrm{m}^{-2}\right.$. day $\left.{ }^{-1}\right)$ in the third period of measurements.

As a matter of fact, burning the cut down forest will release forest bound plant nutrients to the soil. But, only a part of the released nutrients will be available for plant growth. A considerable part of the liberated nutrients will be blown up into the air and spread over a wide area in the form of volatiles and particles. These nutrients, however, will be lost at the clearing, but will contribute to the tight nutrient cycle of nearby forest stands as atmospheric fall-out or wash-out. A considerable amount of plant nutrients wil! be leached through the main root-zone without enabling the crops to use the excessive mass of availabit flant nutrients as the uptake capacity of the crops is limited. In the course of time, the fixation of plant nutrients will occur and the availability of nutrients will be seriously reduced. Aditionally soii structure of the topsoil layer will be affected and temporary soil sterilization occur, which is favourable to agriculture as far as fungal and insect attack on seed and seedings are concerned, but very unfavourable to nitrogen production and $\mathrm{mi}$ corrhizal associations which play an important part in the nutrient uptake of plants. As a matter of fact, fire is a means of unpropriate exploitation of the tropical environiment, es pecially when long-term agricultural schemes for the development of Central Amazonia are proposed.

In slash and burn agriculture the soil $\mathrm{pH}$ remaintal well below the favourable range for important crops. As far as the cacao pilot scheme at the SEMA-site (fig. 1) was concerned, soil $\mathrm{pH}$ had to be corrected by heavy liming. $\mathrm{CaMg}\left(\mathrm{CO}_{3}\right)_{2}$ was applied to the yellow latosols in the order of magnitude of 1200 $\mathrm{Kg} /$ ha. Best growing conditions are obtained, when the soil $\mathrm{pH}$ is stabilized in the range of $\mathrm{pH} 6.0$ to $\mathrm{pH} 7.0$. The increase of the soil pH has an favourable effect on microbial life and the availability of various plant nutrients to the crops. At the SEMA-site a plot of 1100 cacao trees/a was treated with NPK-fertilizer as follows: Nitrogen (urea/46\%N) $65 \mathrm{Kg} / \mathrm{ha}$, Phosphorus (superphosphate $/ 45 \% \mathrm{P}$ ) $200 \mathrm{Kg} / \mathrm{ha}$ and Potassium $\left(\mathrm{K}_{2} \mathrm{O} / 60 \% \mathrm{~K}\right) 73 \mathrm{Kg} / \mathrm{ha}$. It must be emphasized that a heavy treatment with fertilizers is needed to grow perennial crops as cacao, etc. effectively on the yellow latosols along the Manaus-Itacoatiara Road. The short outburst of plant nutrients after burning only enables the growing of some basic crops as maniok, bananas, etc. for at least a couple of years. According to IPEAN (1969), the yellow 
latosols cover about $85 \%$ of the total area along the Road AM-10. As shown above, the agricultural development of these areas is dependent on the use of fertilizer especially phosphates in considerable amounts.

The hydromorphic soil group is limited to only one per cent of the total area of the Tertiary uplands along the Manaus-Itacoatiara Road. Compared with the nutrient conditions of the yellow latosols after the cut down forest was set on fire, increased phosphorus concentrations and low aluminum content in the topsoil layer were favourable, but the availability of calcium and magnesium as well as potassium were worse. Soil fertility after burning is such, that cleared areas on hydromorphic soils may be used for a period of 2 or 3 years for the growing of maniok, pineapple and some other basic crops. After the short growing season these areas will be abandoned and rain forest successions will take over the cleared plots.

As a matter of fact, the profit obtained from tropical agriculture along the ManausItacoatiara Road and areas of a similar environment will be dependent on a favourable exposure of the crops to the impact of the atmospheric controls as solar radiation, air temperature, air humidity and wind, i.e. a particular shaddow-system for a particular crop, and the intensive soil treatment with fertilizers after correction of the soil $\mathrm{pH}$ by means of liming. Aditionally the application of herbicides, insecticides and fungicides is essential for the suppression of root competion and the avoidance of plant deseases.

\section{SUMMARY}

Foram estudadas modificaçốes na composição química do solo na camada superior do solo (até $20 \mathrm{~cm}$ ) em latossolos amarelos (85\% da área total) e solos hidromórficos (cerca de 1\% da área total), an tes e depois da queima da mata derrubada.

Foram obtidos os seguintes resultados:

1 - A fertilidade em condiçōes naturais é baixa nos tipos de solo considerado;

乏 - Durante a queimada, apreciável teor de nutrientes é perdido sob a forma de substâncias voláteis ou sob a forma de partículas;

3 - Uma grande quantidade de nutrientes, é rapidamente liberada e depositada sobre o solo após a queimada;

4 - Grandes quantidades de nutrientes, tempora. riamente disponíveis são perdidas por lixivia. ção uma vez que a capacidade de absorção das plantas supera a disponibilidade de nutrientes;

5 - Uma fixação sólida ređuzirá a disponibilidade atual de nutriente de forma notável;

6 - O retorno de nutrientes pela queimada não é capaz de garantir a longo termo a agricultura tropical;

7 - A correção do $\mathrm{pH}$ e o uso de fertilizantes é necessidade básica para o uso da terra nos trópicos;

8 - O uso de herbicidas, inseticidas e fungicidas é indispensável para reduzir a competição radi. cular e as doenças das plantas;

9 - Condições favoráveis para a proteção das plantas contra o imparto de agentes atmosféricos de sombreamento observadas as exigências de cada cultura.

\section{LITERATURE CITED}

BrinkMANN, W. L. F.

1971 - Nährstoffverluste in Amazonaswälden durch BrasilnuB-Export, U/mschau, 6: 190-191.

Brinkmann, W. L. F. \& Ribeiro, M. N. Góes

1971 - Air temperature in Central Amazonia. II. The effect of near-surface temperatures on land-use in The Terciary region of Central Amazonia. Acta Amazonica, Manaus, 1(3) : 27-32.

BrinkmanN, W. L. F. \& SANTOS, A. DOS

1971 - Natural waters in Amazonia. V. Soluble magnesium properties. Turrialba, 21(4) : 459-465.

1972 - Natural waters in Amazonia. VII. Total phosphorus compound. (in press).

EpinkmanN, W. L, F. \& Vieira, A. N.

1971 - The effect of burning on germination of seeds at different soil deepths of various tropical tree species. Turialba, 21(1) : 77-82.

IPEAN

1969 - Os solos da área Manaus-Itacoatiara. Série Estudos e Ensaios, Belém, 1.: 1-177.

KLINGE, H. \& RODRIgUes, W. A.

1968 - Litter production in an area of Amazonian terra firme forest. II. Mineral nutrient content of the litter. Amazonicna, Kiel, 1(4) .: 303-310.

Rodrigues, W. A.

1967 - Invertário florestal piloto ao longo da estrada Manaus-Itacoatiara, Estado do Amazonas: dados preliminares. Atas Simp. sôbre Biota Amazonica 7 (Conservação da natureza e recursos naturais) : 257-267

SANTOS, U. DE ET ALII

1971 - A composição química do Rio Preto da EvaAmazonia, Estudo Preliminar, Ciêric. Cult., São Paulo, 23(5) : 643-646.

StARK, N.

1971 - The Nutrient content of plants and soils from Brazil and Suriname. Biotropica, 2(1) : 51-60.

TAKEUCHI, $M$.

1961 - The structure of the Amazonian vegetation. II. Tropical Rain forest. Jour. Fac. Sci, Tokyo Univ., Section III : Botany, 8(3): 1-26. 